\title{
PENGARUH CARA PERSALINAN TERHADAP INISIASI LAKTASI
}

\author{
Anna Ismiana ${ }^{1}$, Irwan Taufiqurrahman ${ }^{2}$, Rukmono Siswishanto ${ }^{3}$
}

\begin{abstract}
Background: Breastfeeding on the first day would prevent $16 \%$ of neonatal deaths and if early breastfeeding was given within the first 1 hour would prevent $22 \%$ neonatal of mortality per year.

Objective: To determine the effect of mode of delivery on the initiation of breastfeeding.

Method: The study was prospective cohort. The study was conducted by taking all cases of vaginal delivery and caesarean sections in the obstetric department of Dr. Sardjito, Banjarnegara Hospital, Wates Hospital, Wonosari Hospital and Magelang Hospital that met the criteria from January to May 2014. Maternal data were recorded from the medical records and the data of breast milk secretion within 24 hours after delivery were collected from paramedical personnel who had been trained before. The statistical test that is used was Chi-square.

Results and Discussion: Subjects who met the inclusion criteria consisted of 162 women. Based on the mode of delivery, breastfeeding initiation on the first day after vaginal delivery were done in 73 women $(90,1 \%)$, while in the cesarean delivery group, the initiation were done in only 34 women (42\%). There were no significant relationship between age, education level, women occupation, and parity with the initiation of the first day of postnatal breastfeding. Statistically, BMI $<25 \mathrm{~kg} / \mathrm{m} 2$ had a significant association with 24 hours of postnatal breastfeeding initiation, but not clinically significant. There is a significant association between mode of delivery and the first day of postnatal lactation breastfeeding ( $O R=20,17 ; 95 \% \mathrm{Cl} 7,47$ to 54,$43 ; p=0,000)$.

Conclusions: The proportion of the first day of breastfeeding initiation was larger in vaginal delivery group compared with cesarean delivery group.
\end{abstract}

Keywords: mode of delivery, cesarean section, vaginal delivery, lactation initiation.

\begin{abstract}
ABSTRAK
Latar Belakang: Pemberian Air Susu Ibu (ASI) pada hari pertama akan menyelamatkan 16\% kematian neonatal dan jika menyusu dini dalam 1 jam pertama akan menyelamatkan 22\% kematian balita pertahun dari kematian. Tujuan: Mengetahui pengaruh cara persalinan terhadap inisiasi laktasi.

Metode: Studi kohort prospektif. Penelitian dilakukan dengan mengambil semua kasus persalinan vaginal dan seksio sesarea di RSUP Dr. Sardjito, RSUD Banjarnegara, RSUD Wates, RSUD Wonosari, dan RSUD Magelang yang memenuhi kriteria dari bulan Januari sampai dengan Mei 2014 sampai dengan sampel terpenuhi. Data maternal dicatat dari catatan medis, data penelitian didapat dari melakukan pemeriksaan keluarnya ASI dalam 24 jam pascasalin oleh petugas medis atau paramedis yang telah terlatih. Uji statistik yang digunakan adalah Chi-square. Hasil dan Pembahasan: Subyek penelitian yang memenuhi kriteria inklusi berjumlah 162 orang. Berdasarkan karakteristik cara persalinan, kejadian inisiasi laktasi hari pertama pascasalin pada persalinan vaginal sebanyak 73 orang $(90,1 \%)$, sedangkan pada persalinan secara seksio sesarea sebanyak 34 orang $(42 \%)$. Tidak didapatkan hubungan yang bermakna antara usia, tingkat pendidikan, pekerjaan, dan paritas dengan inisiasi laktasi hari pertama pascasalin. Secara statistik IMT $<25 \mathrm{~kg} / \mathrm{m}^{2}$ memiliki hubungan yang bermakna dengan inisiasi laktasi 24 jam pascasalin, namun tidak bermakna secara klinis. Terdapat hubungan yang bermakna antara cara persalinan dengan inisiasi laktasi hari pertama pascasalin ( $O R=20,17 ; 95 \% \mathrm{Cl} 7,47-54,43 ; p=0,000)$.

Kesimpulan: Proporsi inisiasi laktasi hari pertama pascasalin pada kelompok persalinan vaginal lebih besar dibandingkan dengan kelompok persalinan seksio sesarea.
\end{abstract}

Kata kunci: cara persalinan, seksio sesarea, persalinan vaginal, inisiasi laktasi

1,2,3 Bagian Obstetri dan Ginekologi, Facultas Kedokteran, Universitas Gadjah Mada 


\section{PENDAHULUAN}

Pemberian Air Susu Ibu (ASI) memberikan manfaat jangka panjang bagi ibu maupun anak, termasuk membantu melindungi anak dari sejumlah penyakit akut dan kronis. ASI berisi semua nutrisi yang diperlukan anak dalam enam bulan pertama kehidupan, termasuk lemak, karbohidrat, protein, vitamin, mineral dan air. ASI bisa dicerna dengan mudah dan digunakan dengan efisien. ASI juga berisi faktor bioaktif yang memperkuat sistem imun bayi yang masih belum matur, memberikan perlindungan dari infeksi, dan faktor-faktor lain yang membantu pencernaan dan absorpsi nutrisi. ${ }^{1}$

Hasil penelitian menyatakan bahwa pemberian ASI pada hari pertama akan menyelamatkan $16 \%$ kematian neonatal dan jika menyusu dini dalam 1 jam pertama akan menyelamatkan $22 \%$ balita pertahun dari kematian. ${ }^{2}$ Perlindungan ASI akan semakin meningkat sejalan dengan makin mudanya usia pemberian ASI pada bayi. Beberapa penelitian membuktikan bahwa manfaat pemberian ASI dini yaitu untuk keberlangsungan pemberian ASI ekslusif, mendapatkan kekebalan terhadap berbagai penyakit, mencegah hipotermia, refleks isapan pada puting susu serta pengeluaran hormon oksitosin akan merangsang produksi $\mathrm{ASI}^{3,4}$

Kontak pertama antara ibu dengan bayi baru lahir memiliki hubungan erat dengan prognosis pertumbuhan bayi. Kontak pertama didefinisikan sebagai tindakan pemberian ASI segera setelah persalinan dan Inisiasi Menyusui Dini (IMD) pada bayi. Pemberian ASI dalam satu jam pertama pasca kelahiran akan memberi asupan gizi yang penting sebagai proteksi terhadap berbagai patogen berbahaya pada masa paling rentan kehidupannya.

Satu minggu pertama postpartum adalah sebuah periode penting untuk proses menyusui. Dalam keadaan normal, jumlah ASI yang dihasilkan masih minimal pada 1 hingga 2 hari pertama postpartum, tetapi meningkat secara dramatis pada 2-3 hari postpartum ketika laktogenesis II terjadi sebagai respon terhadap penurunan kadar progesteron setelah persalinan. Selama kurunwaktu ini, baik ibu dan bayi mulai belajar untuk menyusui. Faktor sosiokultural berhubungan kuat dengan dimulainya menyusui, tetapi masalah laktasi sering ditemukan bahkan diantara ibu yang sudah memiliki motivasi kuat untuk menyusui. Masalah seperti keterlambatan onset laktasi dan perilaku menyusui yang suboptimal diantara bayi yang baru lahir, khususnya mereka yang terpapar dengan obat yang digunakan selama persalinan, telah sering dilaporkan. Transfer ASI yang tidak memadai dapat berakibat pada penurunan berat badan bayi yang berlebihan, dehidrasi, dan komplikasi medis serius, atau bahkan kematian. ${ }^{5}$

Berdasarkan data Survei Demografi dan Kesehatan Indonesia (SDKI) tahun 2006 dan 2007 lebih dari 95\%ibu pernah menyusui bayinya, namun yang menyusui dalam 1 jam pertama cenderung menurun dari $8 \%$ pada tahun 2006 menjadi 3,7\% pada tahun 2007 , 46\% kelahiran terjadi di fasilitas kesehatan, dan 79\% dibantu oleh tenaga kesehatan terlatih. Apabila Sepuluh Langkah Keberhasilan Menyusui diterapkan di seluruh fasilitas kesehatan di Indonesia termasuk rumah sakit, klinik bersalin, fasilitas pelayanan kesehatan umum maupun swasta, sekitar dua juta bayi atau separuh dari jumlah bayi yang lahir setiap tahun di Indonesia akan mendapatkan hak mereka terhadap inisiasi menyusui dini dan ASI eksklusif. ${ }^{6}$

Prevalensi seksio sesarea cenderung meningkat dari tahun ke tahun. Di Indonesia, prevalensinya mencapai sekitar $11 \%$ sampai $15 \%$ dan dirumah sakit swasta saat ini dapat mencapai $30 \%$ sampai $40 \%$. Tingginya prevalensi ini dipengaruhi faktor indikasi medis, akan tetapi terdapat pula kecenderungan saat ini untuk melakukan seksio sesarea tanpa adanya indikasi klinis medis, hanya berdasarkan faktor sosial dan pemahaman yang salah dari pasien. Terkadang pihak rumah sakit sendiri banyak yang menyarankan operasi sesar agar tidak merasakan sakit saat persalinan. 
Pada persalinan normal proses pemberian ASI dan IMD dapat dilakukan segera setelah bayi baru lahir. Pasien pasca seksio sesarea mengalami kesulitan untuk melakukan tindakan ini diakibatkan faktor-faktor yang telah disebutkan sebelumnya. Kegagalan IMD akan berpengaruh pada produksi ASI ibu.

Penelitian yang telah dilakukan baik pada binatang maupun manusia mengindikasikan bahwa berbagai stimuli stres dapat menekan laktasi. Stres fisik maupun emosional dapat mengganggu milk ejection reflex dengan menurunkan pelepasan oksitosin selama pemberian ASI. Penelitian observasional mengindikasikan bahwa stres yang mungkin dialami oleh ibu dan janin selama persalinan sesar atau persalinan vaginal yang berlangsung lama berhubungan dengan onset laktasi yang lebih lama. ${ }^{7}$

\section{METODE}

Disain penelitian yang digunakan adalah metode penelitian kohort prospektif. Populasi penelitian adalah semua pasien kehamilan aterm dan postterm yang diterminasi baik dengan persalinan pervaginal maupun seksio sesarea di RSUP Dr Sardjito dan RSUD jejaring periode 1 Januari 2014 hingga sampel terpenuhi. Subyek penelitian adalah pasien yang memenuhi kriteria inklusi.

Didapatkan 162 sampel yang masing-masing dibagi dalam dua kelompok. Kelompok pertama adalah kelompok dengan persalinan vaginal, sedang kelompok kedua adalah persalinan dengan seksio sesarea. Kriteria inklusi pada penelitian ini adalah pasien dengan usia kehamilan $>37$ minggu, bayi dirawat gabung, ASI belum keluar sebelum bayi lahir, dan bersedia mengikuti penelitian. Sedangkan kriteria eksklusi adalah kontraindikasi menyusui pascasalin dan tidak bersedia mengikuti penelitian.

Data maternal dicatat dari catatan medis, data penelitian didapat dari melakukan pemeriksaan produksi ASI dalam 24 jam pascasalin pada payudara ibu. Pemeriksaan produksi ASI hari pertama pada payudara ibu akan dilakukan oleh petugas medis atau paramedis yang telah terlatih.

Data penelitian dianalisis dengan analisis univariat, bivariat dan multivariat.

\section{HASIL DAN PEMBAHASAN}

Selama penelitian didapatkan subyek yang mengalami inisiasi laktasi sebanyak 107 orang (66,05\%) dan yang tidak mengalami inisiasi laktasi 55 orang (33,95\%). Dari 162 subyek, wanita dengan usia <35 tahun ditemukan pada 136 (84\%) subyek. Seratus delapan $(66,7 \%)$ subyek memiliki tingkat pendidikan $\geq 9$ tahun. Subyek dari kelompok bekerja didapatkan sebanyak 108 (66,7\%). IMT $\geq 25 \mathrm{~kg} / \mathrm{m} 2$ (kelompok obesitas) ditemukan pada 160 (98,8\%) subyek. Wanita primipara ditemukan pada 96 $(59,3 \%)$ subyek. 
Tabel 1. Komparabilitas subyek penelitian

\begin{tabular}{|c|c|c|c|c|c|c|}
\hline \multirow{3}{*}{ Variabel } & \multicolumn{4}{|c|}{ Cara Persalinan } & \multirow{3}{*}{$x^{2}$} & \multirow{3}{*}{$p$} \\
\hline & \multicolumn{2}{|c|}{ Vaginal } & \multicolumn{2}{|c|}{$\mathrm{SC}$} & & \\
\hline & $\mathrm{n}$ & $\%$ & $\mathrm{n}$ & $\%$ & & \\
\hline \multicolumn{7}{|l|}{ Usia } \\
\hline$<35$ tahun & 71 & 52,2 & 65 & 47,8 & 1,649 & 0,199 \\
\hline$\geq 35$ tahun & 10 & 38,5 & 16 & 61,5 & & \\
\hline \multicolumn{7}{|l|}{ Pendidikan } \\
\hline$=9$ tahun & 54 & 50 & 54 & 50 & 0,000 & 0,348 \\
\hline$<9$ tahun & 27 & 50 & 27 & 50 & & \\
\hline \multicolumn{7}{|l|}{ Pekerjaan } \\
\hline Bekerja & 53 & 49,1 & 55 & 50,9 & 0,111 & 0,557 \\
\hline Tidak Bekerja & 28 & 51,9 & 26 & 48,1 & & \\
\hline \multicolumn{7}{|l|}{ IMT $\left(\mathrm{kg} / \mathrm{m}^{2}\right)$} \\
\hline$<25$ & 32 & 58,18 & 23 & 41,82 & 2,230 & 0,135 \\
\hline$\geq 25$ & 49 & 45,79 & 58 & 54,21 & & \\
\hline \multicolumn{7}{|l|}{ Paritas } \\
\hline Multipara & 54 & 56,3 & 42 & 43,8 & 3,682 & 0,055 \\
\hline Primipara & 27 & 40,9 & 39 & 59,1 & & \\
\hline
\end{tabular}

Tabel 1 di atas menggambarkan komparabilitas antar kelompok untuk mengetahui data dasar yang berbeda. Tabel ini menunjukkan bahwa semua variabel luar pada penelitian ini tidak terdapat perbedaan secara bermakna atau homogen $(p>0,05)$.

Tabel 2. Analisis bivariat hubungan cara persalinan dengan inisiasi laktasi

\begin{tabular}{|c|c|c|c|c|c|c|}
\hline \multirow{3}{*}{ Variabel } & \multicolumn{4}{|c|}{ Inisiasi Laktasi } & \multirow{3}{*}{$\operatorname{RR}(95 \% \mathrm{Cl})$} & \multirow{3}{*}{$p$} \\
\hline & \multicolumn{2}{|c|}{$\mathrm{Ya}$} & \multicolumn{2}{|c|}{ Tidak } & & \\
\hline & $\mathrm{n}$ & $\%$ & $\mathrm{n}$ & $\%$ & & \\
\hline Vaginal & 73 & 90,1 & 8 & 9,9 & $2,15(1,65-2,80)$ & 0,000 \\
\hline Seksio sesarea & 34 & 42 & 47 & 58 & & \\
\hline
\end{tabular}

Analisis bivariat dilakukan untuk mengetahui hubungan antara variabel bebas dan terikat, juga variabel luar dengan variabel terikat. Berdasarkan karakteristik cara persalinan, inisiasi laktasi pada persalinan vaginal sebanyak 73 orang $(90,1 \%)$, sedangkan pada persalinan secara seksio sesarea inisiasi laktasi sebanyak 34 orang (42\%). Terdapat hubungan yang bermakna antara cara persalinan dengan inisiasi laktasi hari pertama pascasalin $(p=0,0000 ; R R=2,15 ; C l$ 95\% 1,65-2,80). Dengan demikian cara persalinan mempengaruhi inisiasi laktasi hari pertama pascasalin. 
Tabel 3. Hubungan beberapa variabel luar terhadap inisiasi laktasi

\begin{tabular}{|c|c|c|c|c|c|c|}
\hline \multirow{3}{*}{ Variabel } & \multicolumn{4}{|c|}{ Inisiasi Laktasi } & \multirow{3}{*}{$\operatorname{RR}(95 \% \mathrm{Cl})$} & \multirow{3}{*}{$p$} \\
\hline & \multicolumn{2}{|c|}{$\mathrm{Ya}$} & \multicolumn{2}{|c|}{ Tidak } & & \\
\hline & $\mathbf{n}$ & $\%$ & $\mathrm{n}$ & $\%$ & & \\
\hline \multicolumn{7}{|l|}{ Usia } \\
\hline$<35$ tahun & 88 & 64,7 & 48 & 35,3 & $0,89(0,68-1,15)$ & 0,409 \\
\hline$\geq 35$ tahun & 19 & 73,1 & 7 & 26,9 & & \\
\hline \multicolumn{7}{|l|}{ Pendidikan } \\
\hline$\geq 9$ tahun & 74 & 68,5 & 34 & 31,5 & $1,12(0,88-1,44)$ & 0,348 \\
\hline$<9$ tahun & 33 & 61,1 & 21 & 38,9 & & \\
\hline \multicolumn{7}{|l|}{ Pekerjaan } \\
\hline Bekerja & 73 & 67,6 & 35 & 32,4 & $1,07(0,84-1,37)$ & 0,557 \\
\hline Tidak Bekerja & 34 & 63 & 20 & 37 & & \\
\hline \multicolumn{7}{|l|}{ IMT $\left(\mathrm{kg} / \mathrm{m}^{2}\right)$} \\
\hline$<25$ & 32 & 58,18 & 23 & 41,82 & $0,83(0,64-1,07)$ & 0,129 \\
\hline$\geq 25$ & 75 & 70,09 & 32 & 29,91 & & \\
\hline \multicolumn{7}{|l|}{ Paritas } \\
\hline Multipara & 67 & 69,8 & 29 & 30,2 & $1,15(0,91-1,46)$ & 0,225 \\
\hline Primipara & 40 & 60,6 & 26 & 39,4 & & \\
\hline
\end{tabular}

Hasil uji statistik pada tabel 3 menunjukkan bahwa terdapat hubungan yang bermakna antara cara persalinan terhadap inisiasi laktasi $(p=0,000$; $95 \% \mathrm{Cl} 1,65-2,80)$. Sedangkan untuk variabel yang lain seperti usia $(p=0,409 ; 95 \% \mathrm{Cl} 0,68-1,15)$, pendidikan ( $\mathrm{p}=0,348 ; 95 \% \mathrm{Cl}$ 0,88-1,44), pekerjaan ( $p=0,557 ; 95 \% \mathrm{Cl} 0,84-1,37), \mathrm{IMT}(\mathrm{p}=0,129 ; 95 \% \mathrm{Cl}$ $(0,64-1,07)$ dan paritas $(p=0,225 ; 95 \% \mathrm{Cl} 0,91-1,46)$ tidak menunjukkan hubungan yang bermakna dengan inisiasi laktasi.

Tabel 4. Hubungan antara cara persalinan dengan inisiasi laktasi dengan mengendalikan faktor-faktor luar yang mempengaruhi

\begin{tabular}{|c|c|c|c|c|}
\hline Variabel & $\mathrm{B}$ & Exp B & $95 \% \mathrm{Cl}$ & $p$ \\
\hline \multicolumn{5}{|l|}{ Cara persalinan } \\
\hline Vaginal & 3,004 & 20,166 & $7,47-54,43$ & 0,000 \\
\hline \multicolumn{5}{|l|}{ SC } \\
\hline \multicolumn{5}{|l|}{ Usia } \\
\hline $\begin{array}{l}<35 \text { tahun } \\
\geq 35 \text { tahun }\end{array}$ & $-0,780$ & 0,458 & $0,15-1,44$ & 0,182 \\
\hline \multicolumn{5}{|l|}{ Pēndidikan } \\
\hline \multicolumn{5}{|l|}{$<9$ tahun } \\
\hline \multicolumn{5}{|l|}{ Pekerjaan } \\
\hline Bekerja & $-0,507$ & 0,602 & $0,26-1,41$ & 0,242 \\
\hline \multicolumn{4}{|l|}{ IMT $\left(\mathrm{kg} / \mathrm{m}^{2}\right)$} & \\
\hline$<25$ & $-1,260$ & 0,284 & $0,11-0,71$ & 0,008 \\
\hline \multicolumn{5}{|l|}{$\geq 25$} \\
\hline \multicolumn{5}{|l|}{ Paritas } \\
\hline Multipara & $-0,176$ & 0,839 & $0,36-1,95$ & 0,682 \\
\hline Primipara & & & & \\
\hline
\end{tabular}


Analisis multivariat dilakukan untuk mengetahui hubungan antara beberapa faktor yang berpengaruh terhadap inisiasi laktasi secara bersamaan dengan menggunakan analisis regresi logistik seperti terlihat pada tabel 4. Dari tabel di bawah dapat digambarkan bahwa faktor yang berpengaruh terhadap inisiasi laktasi adalah cara persalinan $(\mathrm{OR}=20,17 ; 95 \% \mathrm{Cl}$ 7,47-54,43; $p=0,000)$ dan IMT $<25 \mathrm{~kg} / \mathrm{m}^{2}$ (OR=0,28; $95 \% \mathrm{Cl} 0,11-0,71 ; p=0,008)$.

Selama kurun waktu Januari-Mei 2014 didapatkan 162 sampel yang memenuhi kriteria inklusi yaitu pasien dengan usia kehamilan >37 minggu dengan kehamilan tunggal, ASI belum keluar sebelum bayi lahir, bayi dirawat gabung, dan bersedia mengikuti penelitian.

Berdasarkan karakteristik cara persalinan, inisiasi laktasi hari pertama pascasalin pada persalinan vaginal sebanyak 73 orang $(90,1 \%)$, sedangkan pada persalinan secara seksio sesarea sebanyak 34 orang (42\%). Terdapat hubungan yang bermakna antara cara persalinan dengan inisiasi laktasi hari pertama pascasalin. Dengan demikian cara persalinan mempengaruhi inisiasi laktasi hari pertama pascasalin. Proporsi inisiasi laktasi hari pertama pascasalin pada persalinan vaginal lebih besar 20,17 kali lebih besar dibandingkan dengan pada persalinan seksio sesarea. Hal ini sejalan dengan penelitian yang menyatakan bahwa wanita yang proses persalinannya dengan seksio sesarea akan mengalami onset laktasi yang lebih lambat dibandingkan dengan persalinan normal karena proses pembedahan akan menghambat proses produksi ASI. ${ }^{8}$ Penelitian lain menunjukkan bahwa ada perbedaan yang bermakna dalam lama waktu hingga laktasi antara kelompok persalinan vaginal dan persalinan seksio cesarean. Rata-rata lama waktu hingga pemberian ASI pertama pada kelompok persalinan vaginal adalah $60 \pm 93$ menit, sedangkan pada kelompok persalinan seksio sesarea adalah $234 \pm 228$ menit $(p<0,05) .{ }^{9}$ Ditunjukkan dalam penelitian oleh menunjukkan bahwa ada perbedaan yang bermakna dalam lama waktu hingga keluar ASI di antara tipe persalinan yang berbeda $(p=0,001)$, tetapi tidak ada perbedaan yang ditemukan antara seksio sesarea elektif dan seksio sesarea dengan nyeri bersalin $(p=0,741)$. Peneliti menemukan bahwa lama waktu hingga keluar ASI memiliki korelasi yang kuat dengan tipe persalinan. ${ }^{7}$ Pada penelitian lain dinyatakan bahwa kecemasan, paritas, dan metode persalinan berhubungan dengan lamanya ASI keluar. ${ }^{10}$ Secara teori, diterangkan bahwa keluarnya ASI pada 1-2 hari setelah persalinan sangat sedikit kemudian meningkat pada hari 2-3 setelah persalinan. Setelah pelepasan plasenta pada proses persalinan maka akan terjadi penurunan hormon progesteron dan estrogen dalam darah dan pengaruh isapan pada puting susu ibu yang memicu terbentuknya prolaktin yang akan merangsang produksi ASI. $^{6}$

Faktor yang mempengaruhi keberlangsungan menyusui yaitu status pendidikan, sosial ekonomi, usia ibu, status pekerjaan ibu, kebiasaan merokok, keyakinan ibu (pengalaman, percaya diri), dan dukungan. Hal ini bertentangan dengan penelitian ini dimana tidak didapatkan hubungan yang bermakna antara usia, tingkat pendidikan, pekerjaan, IMT dan paritas dengan inisiasi laktasi. ${ }^{11}$ Dikemukakan bahwa tidak didapatkan hubungan antara onset laktasi dengan usia ibu. Dalam penelitiannya disebutkan pula seiring dengan meningkatnya usia seorang primipara menunjukkan onset laktasi meningkat 1 jam per tahunnya. ${ }^{8}$ Penelitian lain juga menyatakan bahwa tidak terdapat hubungan bermakna antara usia dan onset laktasi. Dari 200 total subyek penelitian, 97 orang berusia kurang dari 26 tahun, dimana 76 orang (38\%) memiliki onset laktasi yang normal, sisanya 21 orang $(10,5 \%)$ mengalami keterlambatan onset laktasi. ${ }^{12}$ Onset laktasi terjadi lebih lambat pada primipara dibandingkan multipara. Pada penelitian ini didapatkan hasil yang tidak bermakna secara statistik sehingga disimpulkan tidak terdapat hubungan bermakna antara paritas dengan inisiasi laktasi 24 jam pascasalin. ${ }^{8}$

Dari hasil analisis multivariat didapatkan bahwa faktor yang berpengaruh terhadap inisiasi laktasi 
adalah cara persalinan dan IMT $<25 \mathrm{~kg} / \mathrm{m}^{2}$. Secara statistik IMT $<25 \mathrm{~kg} / \mathrm{m}^{2}$ memiliki hubungan yang bermakna dengan inisiasi laktasi 24 jam pascasalin, namun tidak bermakna secara klinis. Hal ini bertentangan dengan penelitian yang menunjukkan tidak ada hubungan yang signifikan antara IMT dengan onset laktasi. ${ }^{13}$ Secara teori laporkan bahwa wanita yang mengalami obesitas mempunyai kadar progesteron yang tinggi sehingga ibu yang gemuk memiliki kadar prolaktin yang rendah sebagai respon isapan bayi dalam 48 jam pertama namun mekanisme hubungan antara IMT dengan onset laktasi belum diterangkan secara jelas. ${ }^{14} \mathrm{Hubung}$ an yang kompleks diantara berbagai faktor yang mungkin mempengaruhi laktogenesis, mempersulit peneliti untuk memisahkan efek stres dari efek yang disebabkan karena variabel lain. Ketika laktogenesis II terganggu, berakibat pada keterlambatan onset produksi susu, volume susu yang tidak mencukupi, dan/atau penurunan berat badan, masalah ini bisa disebabkan karena kombinasi hasil dari stres dengan satu atau lebih faktor maternal, bayi, atau lingkungan.$^{15}$

Pada penelitian ini, tidak memperhitungkan penyakit-penyakit penyerta, obat-obatan dan praktik IMD serta tidak dilakukan periode follow up sehingga tidak diketahui keberlangsungan keberhasilan inisiasi laktasi hari pertama pascasalin pada pemberian ASI ekslusif.

\section{KESIMPULAN DAN SARAN}

Proporsi inisiasi laktasi hari pertama pascasalin lebih besar pada kelompok persalinan vaginal dibandingkan dengan kelompok persalinan seksio sesarea.

Penelitian lebih lanjut perlu dilakukan dengan memperhitungkan penyakit penyerta dan inisiasi menyusu dini. Penelitian lebih lanjut juga dapat ditujukan untuk mencari faktor lainnya yang dapat mempengaruhi inisiasi laktasi hari pertama pascasalin. Perlu dilakukan periode follow up untuk mengetahui keberhasilan pemberian ASI jangka panjang. Perlunya mengurangi tingkat persalinan secara seksio sesarea secara bijak dan mendorong persalinan vaginal agar tercapai pemberian ASI sedini mungkin. Pemberian analgetik yang adekuat pada ibu pascasalin secara seksio sesarea dengan mempertimbangkan efeknya terhadap produksi ASI.

\section{DAFTAR PUSTAKA}

1. 2009. Infant and Young Child Feeding: Model Chapter for textbooks for medical students and allied health professionals. Geneva: World Health Organization.

2. Edmond, M., Zandoh, C., Quigley, A.M., Etego, A.S., Agyei, O. \& Kirkwood, B. 2006. Delayed breastfeeding initiation increased risk of neonatal mortality. Pediatrics, 117:380-386.

3. Gartner, L., Morton, J., Lawrence, R. \& Al, E. 2005. Breastfeeding and the use of human milk. American academy of pediatrics, 115(2): 496-506.

4. Gupta, A. 2007. Initiating breastfeeding within in one hour of birth. World Breastfeeding Week (WBW).

5. Kementerian Kesehatan RI. 2010. Pedoman Pekan ASI Sedunia (PAS) 2010. Jakarta: Kementerian Kesehatan RI.

6. Dewey, K.G., Rivers, L.A.N., Heinig, M.J. \& Cohen, R.J. 2003. Risk factors for suboptimal infant breastfeeding behavior, delayed onset of lactation, and excess neonatal weight loss. American academy of pediatrics. 112(3):607-19.

7. Sakha, K. \& Behbahan, A.G.G. 2005. The onset time of lactation after delivery. Medical Journal of The Islamic Republic of Iran. 19(2):135-139.

8. Hildebrandt, H.M. 1999. Maternal perception of lactogenesis time: A clinical report. J Hm Lact, 15(4):317-323.

9. Chen, D.C., Rivers, L.N., Dewey, K.G., Lonnerdal, B. 1998. Stress during labor and delivery and early lactation performance. Am J Clin Nutr. August vol. 68 no. 2 335-344.

10. Grajeda, R. \& Escamilla, R.P. 2002. Stress during labour and delivery is associated with delayed onset of lactation among urban Guatemalan women. The Journal of Nutrition: 3055-3060.

11. Haku, M. 2007. Factor associated with the continuation of breastfeeding, the current situation in Japan, and recommendations for 
further research. The Journal of Medical Investigation. 54:224-234.

12. Salahudeen, M.S., Koshy, A.M., Sen, S. 2013. A study of the factors affecting time to onset of lactogenesis-ll after parturition. Journal of Pharmacy Research. 6:68-72.

13. Scott, J.A.\& Binns, C.O., Wendy, H. 2007. Predictor of delayed onset of lactation. Maternal and Child Nutrition, 3(3):186-193.
14. Rivers, L.A.N., Chantry, C.J., Peerson, J.M., Cohen, R.J., Dewey, K.G. 2010. Delayed onset of lactogenesis among first-time mothers is related to maternal obesity and factors associated with ineffective breastfeeding. Am J Clin Nutr. 92:57484

15. Dewey, K. 2001. Maternal and fetal stress are associated with impaired lactogenesis in human. $J$ Nutr. 131:3012S-3015S. 